\title{
36. DATA REPORT: GEOCHEMICAL LOGGING RESULTS FROM VANUATU: SITES 829, 830, 831, AND $833^{1}$
}

\author{
James F. Bristow, ${ }^{2}$ Roy E. Dove, ${ }^{3}$ Cristina Broglia, ${ }^{4}$ Michael A. Hobart, ${ }^{4}$ Thierry J. Chabernaud, ${ }^{4}$ and Jennifer Tivy ${ }^{4}$
}

\begin{abstract}
Geochemical well logs were obtained in the igneous and sedimentary sequences drilled at Sites $829,830,831$, and 833 of Ocean Drilling Program Leg 134. Corrections have been applied to the logs to account for variations in borehole size, borehole fluid composition, downhole temperature, and logging speed. Concentrations of the elements $\mathrm{Th}, \mathrm{U}$, and $\mathrm{Gd}$, and the dry weight percentages of the oxides of $\mathrm{Si}, \mathrm{Ca}, \mathrm{Al}, \mathrm{Fe}, \mathrm{Ti}$, and $\mathrm{K}$ have been derived. In each of the logged holes the log-derived geochemistry agrees well with shipboard carbonate-derived $\mathrm{CaO}$ and $\mathrm{X}$-ray fluorescence core measurements.
\end{abstract}

\section{INTRODUCTION}

The New Hebrides Island Arc lies in the southwest Pacific Ocean (Fig. 1), marking the subduction zone of the Australia-India plate, which moves eastward beneath the North Fiji Basin and the Pacific plate. The primary objectives of Ocean Drilling Program (ODP) Leg 134 were to investigate the complex tectonic and magmatic evolution of this arc and the processes involved in the evolution of an intra-arc basin. Seven sites were drilled, and four holes were logged with the geochemical tool string: Holes $829 \mathrm{~A}$ and $830 \mathrm{C}$, situated on the forearc slope of the New Hebrides Island Arc; Hole 831B, on the summit platform of the Bougainville Guyot; and Hole 833B, east of the island arc on the lower east flank of the North Aoba Basin.

Geochemical logs provide continuous, in-situ measurements of the major rock-forming elements in the formation at $0.1524 \mathrm{~m}$ (6 in.) intervals. They provide a large database of geochemical information unaffected by problems such as incomplete or preferential core recovery and core disturbance, which afflict core-based studies.

This report describes the hole conditions and logging operations for each hole logged with the geochemical tool string, discusses the function of each tool on the string, explains the data processing techniques, and qualitatively compares the processed elemental and oxide data from the logs with lithostratigraphic descriptions and core measurements.

\section{DATA ACQUISITION}

\section{Site 829}

Site 829 lies within the collision zone of the d'Entrecasteaux Zone along the forearc slope of the New Hebrides Island Arc. Hole 829A penetrated $590.3 \mathrm{~m}$ of sedimentary and igneous rocks with $33.4 \%$ recovery. Hole $829 \mathrm{~B}$ was drilled through sediments to $19.5 \mathrm{mbsf}$ with $80 \%$ recovery; Hole $829 \mathrm{C}$ was drilled through sediments to $58.4 \mathrm{mbsf}$ with $90.2 \%$ recovery.

To prepare Hole 829A for logging, a wiper trip was made between 580 and $91 \mathrm{mbsf}$, where the pipe was set for logging operations. Five logging runs were made in all, and hole conditions were generally good. The quad-combination tool string, consisting of the natural gamma-ray spectrometry tool (NGT), the long-spacing sonic tool (SDT), the lithodensity tool (HLDT), and the dual induction tool

\footnotetext{
${ }^{1}$ Greene, H.G., Collot, J.-Y., Stokking, L.B., et al., 1994. Proc. ODP, Sci. Results, 134: College Station, TX (Ocean Drilling Program).

${ }^{2}$ Borehole Research, Department of Geology, University of Leicester, Leicester, LEI 7RH, United Kingdom.

${ }^{3}$ Schlumberger-Doll Research, Ridgefield, CT 06877-4108, U.S.A.

4 Borehole Research Group, Lamont-Doherty Earth Observatory, Columbia University, Palisades, NY 10964, U.S.A.
}

(DITE), was the first to be run, from 475 to 50 meters below seafloor (mbsf). The formation microscanner tool string, consisting of the NGT, the general purpose inclinometer, and the formation microscanner (FMS) tools, was run from 473 to $49 \mathrm{mbsf}$. The geochemical logging tool string (GLT), consisting of the NGT, the aluminum activation clay tool (AACT), and the gamma-ray spectrometry tool (GST), was run third to record data from 476 to $155 \mathrm{mbsf}$. The digital borehole televiewer (BHTV) was run from 429 to 155 mbsf. The final logging run was made with a new magnetic susceptibility tool (Shipboard Scientific Party, 1992a).

\section{Site $\mathbf{8 3 0}$}

Site 830 is located on the forearc slope in the collision zone between the Bougainville Guyot and the central New Hebrides Island Arc. The site was chosen to penetrate a thrust slice in the forearc, where thin superficial sedimentary rocks appear to overlie a strongly reflective acoustic basement. Three holes were drilled at this site: Hole $830 \mathrm{~A}$, drilled to 96.9 mbsf with $55.5 \%$ recovery; Hole $830 \mathrm{~B}$, washed to $48.5 \mathrm{mbsf}$, then cored to $281.7 \mathrm{mbsf}$, with $20.9 \%$ recovery; and Hole $830 \mathrm{C}$, washed to $235.0 \mathrm{mbsf}$, then cored to $350.6 \mathrm{mbsf}$, with $16.8 \%$ recovery.

Pipe was set at $51.6 \mathrm{mbsf}$ in Hole $830 \mathrm{C}$, and two logging runs were completed. The first run was made with the quad-combination tool string, which logged data from 272 to 11 mbsf. The second run was made with the geochemical tool string, which logged data from 247 to $40 \mathrm{mbsf}$, over two logging passes. Hole conditions were generally poor with increasing fill during logging operations; indeed, a very large borehole diameter precluded the use of the FMS at this hole (Shipboard Scientific Party, 1992b).

\section{Site 831}

Site 831 is located on the summit platform of the Bougainville Guyot, just west of the New Hebrides Island Arc subduction zone. The main objectives at this site were to determine if the carbonate cover was suitable as a sea-level indicator and to ascertain the age of the basement. Hole $831 \mathrm{~A}$ was drilled to $116.5 \mathrm{mbsf}$ with $22.4 \%$ recovery. After washing to $102.4 \mathrm{mbsf}$ in Hole $831 \mathrm{~B}$, drilling penetrated to 852.0 mbsf with only $11.6 \%$ recovery; volcanics were reached beneath the carbonate cover.

Pipe was set at $101 \mathrm{mbsf}$ in Hole 831B for the quad-combination tool string, which logged data from 818 to 62 mbsf. Pipe was raised to $82 \mathrm{mbsf}$, and the FMS tool string was run from 755 to 83 mbsf. Two runs of the geochemical combination recorded data from 755 mbsf to the seafloor. The susceptibility, magnetometer, and BHTV tools were also run. Logging conditions were generally good at this hole (Shipboard Scientific Party, 1992c). 


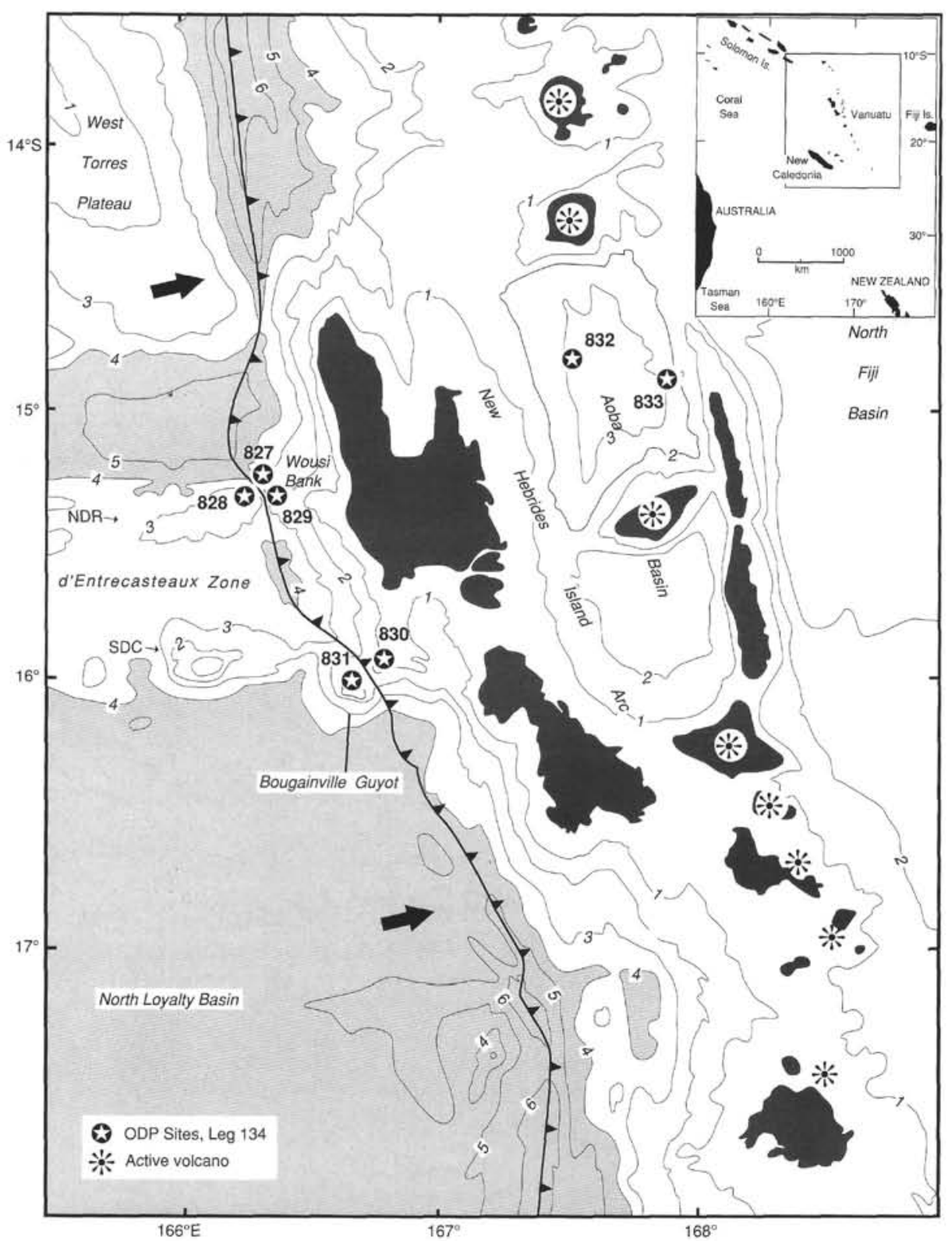

Figure 1. Location of Leg 134 drill sites, Vanuatu, southwest Pacific Ocean. Bathymetry in kilometers.

\section{Site 833}

Site 833 is located on the lower east-central flank of the North Aoba Basin. Two holes were drilled at this site: Hole $883 \mathrm{~A}$ penetrated 199.5 mbsf with $49.0 \%$ recovery; Hole $833 \mathrm{~B}$ was drilled to 1001.1 mbsf with $56.2 \%$ recovery.

Drill pipe was set relatively deep in Hole $833 \mathrm{~B}$ at $250 \mathrm{mbsf}$ to avoid the poor hole conditions found in the shallower part of the hole. The quad-combination tool string, run first, recorded data from 887 mbsf to the end of pipe at $250 \mathrm{mbsf}$. Due to hole problems, a full wiper trip was made, and the pipe was re-set at $540 \mathrm{mbsf}$. The FMS tool string was then run from 934 to $557 \mathrm{mbsf}$. The third tool string, the geochemical, was run from 885 to 557 mbsf; a short section was recorded through pipe from 450 to $408 \mathrm{mbsf}$. The final logging run of the magnetometer tool was made from 866 to 540 mbsf, but the data were badly affected by the adverse hole conditions (Shipboard Scientific Party, 1992d).

\section{GEOCHEMICAL LOGGING TOOL}

Nuclear geochemical logging uses three separate modes of gammaray spectroscopy to obtain a comprehensive elemental analysis of the formation. The GLT deployed in ODP operations consists of four tool components (Fig. 2). At the top of the string an NGT measures the spectrum of natural gamma radiation of the formation with a sodium iodide scintillation detector, from which the concentrations of $\mathrm{K}$, Th, and $U$ are derived (Lock and Hoyer, 1971). The NGT precedes the other tools as it ascends the borehole, measuring the natural gamma-ray activity of the formation before the nuclear sources of the tools below irradiate the formation. The second tool on the string, an AACT, takes measurements from which the concentration of $\mathrm{Al}$ in the formation is derived (Scott and Smith, 1973). The AACT measures the gamma rays produced by delayed neutron activation induced by a ${ }^{252}$ californium (Cf) source, which the CNT-G above the AACT carries. The GST, at the bottom of the tool string, consists of a "minitron" tritium source of 
pulsed $14 \mathrm{MeV}$ neutrons and a gamma-ray scintillation detector. Incident neutrons lose energy through scattering interactions and, on reaching thermal energies, are captured by elemental nuclei, causing the emission of gamma rays. The spectrum of gamma rays detected can be used in conjunction with data from the NGT and AACT to derive the weight percentages of the elements $\mathrm{Si}, \mathrm{Fe}, \mathrm{Ca}, \mathrm{S}, \mathrm{Ti}$, and $\mathrm{Gd}$. The GST also measures the contribution of $\mathrm{Cl}$ and $\mathrm{H}$, from both the borehole and the formation, to the detected spectrum.

The only major elements in the formation not measured by the geochemical tool string are magnesium $(\mathrm{Mg})$ and sodium $(\mathrm{Na})$. Neither of these elements has a sufficiently large capture cross section relative to its typical abundance to be detected by the GST (Hertzog et al., 1989). An estimate of their concentrations can be derived from the photoelectric factor (PEF) of the lithodensity tool. The recorded $\mathrm{PEF}$ log is compared to a computed PEF derived from a summation of the photoelectric contributions from the GLT-measured elements. Any difference is attributed to unmeasured elements in the formation (i.e., $\mathrm{Mg}$ and $\mathrm{Na}$ ). This calculation, however, requires very high quality data from both the lithodensity tool and the GLT, in addition to a reasonable abundance of these elements in the formation. These criteria were not met in any of the logged holes described, and the calculation was, therefore, not performed.

\section{DATA REDUCTION}

During logging operations aboard JOIDES Resolution the data are transmitted electronically up the conductive logging cable and recorded digitally in the Schlumberger Cyber Service Unit (CSU). Some preliminary processing of the data occurs at this time to produce field logs, which are immediately available to the shipboard scientific party for initial interpretation. Subsequent post-cruise processing on shore allows for more comprehensive environmental corrections for borehole size, logging speeds, borehole-fluid salinity, temperature, and pipe effects. Processing of the GST spectrometry data is required to trans-

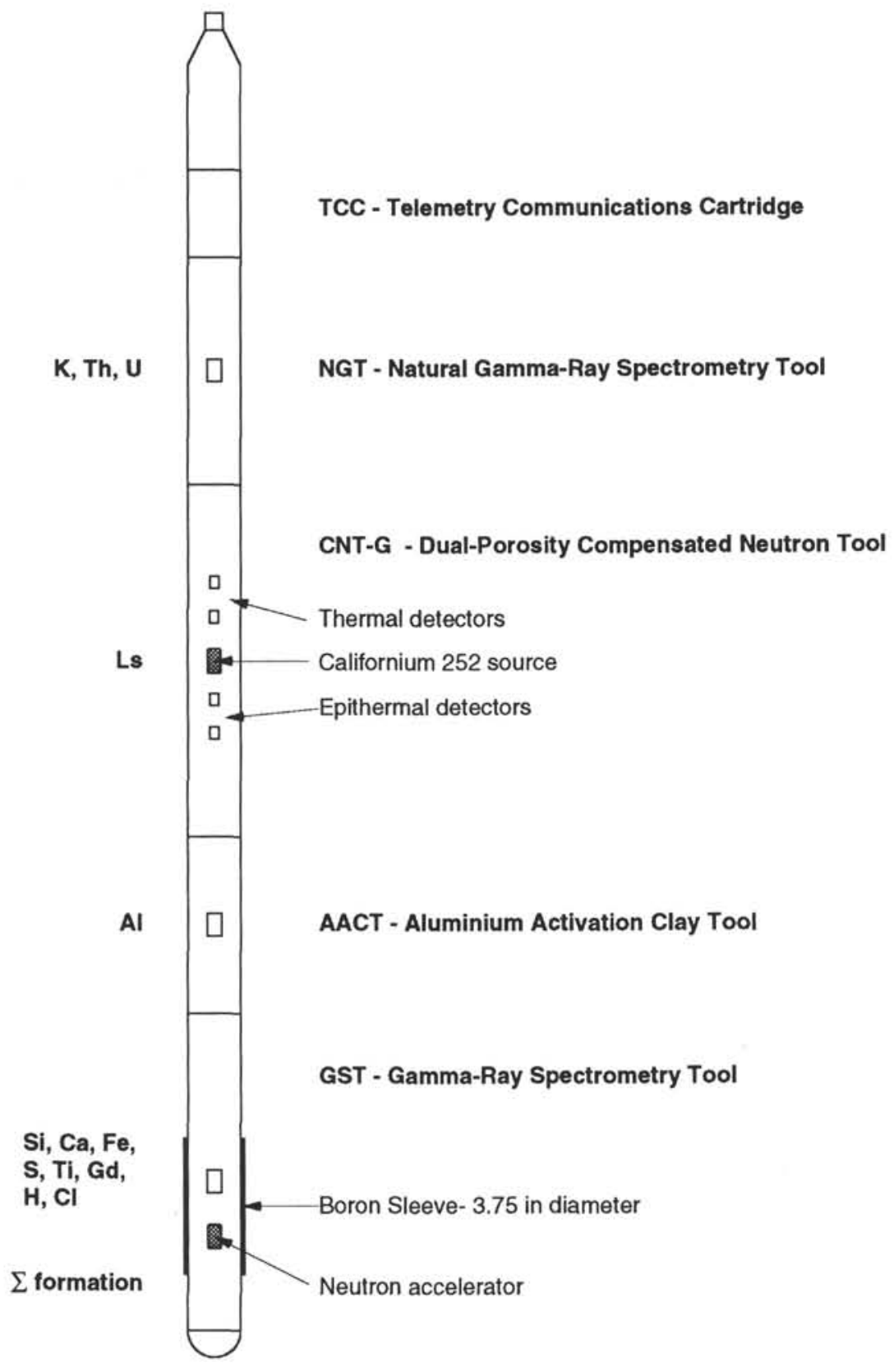

Figure 2. Schematic drawing of the geochemical logging tool string. 
form them into elemental-oxide weight fractions. The processing is performed using a series of programs written by Schlumberger, described below. The processing flow is summarized in Figure 3 .

\section{Reconstruction of the Relative Elemental Yields from the Recorded Spectra}

The first step of processing determines from the measured spectra of the GST the relative contribution of each element (yield) to the total recorded spectrum. The basic model of this program assumes that each downhole spectrum can be represented as a linear combination of a set of "standards," or basis spectra. These standards approximate the spectrum of each element and are combined with the recorded spectrum in a weighted, least-squares inversion at each depth level to determine the relative elemental yields.

Shipboard CSU processing has a standard six-element inversion that solves for $\mathrm{Si}, \mathrm{Ca}, \mathrm{Cl}, \mathrm{H}, \mathrm{S}$, and $\mathrm{Fe}$ only. These six elements provide a useful framework for initial shipboard interpretation. Post-cruise processing typically utilizes the additional spectra of Ti, Gd, and K, which have been shown substantially to improve the fit of the elements to the recorded spectra (Grau and Schweitzer, 1989).

It is possible to remove and substitute other standards (elements) at this stage of the fitting process. In some environments logged by ODP certain elements are below the detection resolution of the tool (Bristow and deMenocal, 1992; Jarrard and Lyle, 1991). This is more often the case in high-porosity environments, where most of the detected gamma-ray spectrum is derived from $\mathrm{Cl}$ and $\mathrm{H}$ in the formation and borehole, rather than from the rock matrix. $\mathrm{S}$ and $\mathrm{K}$ were found by experimentation to be below the resolution of the GST in Holes 829A and 830C. These unresolved elements were found to introduce instability into the inversion, inducing significant noise in the remaining elements; they were, therefore, omitted from the calculation of the elemental yields. In Holes 831B and 833B the full set of nine elemental standards were used. Simple arithmetic averaging, using a 7-point ( $3.5 \mathrm{ft})$, moving window, was applied to the output yields of all of the holes to reduce noise in the data.

\section{Depth Shifting}

Geochemical processing involves the integration of data from different tool strings. Consequently, it is important that all the data are depth correlated to one reference logging run. This is done using the natural gamma-ray curve from the NGT, which is run on each tool string. The reference run is selected after considering the nature of the cable tension, which indicates the degree of tool sticking, and the logging speed. Faster logging runs are less susceptible to data degradation caused by the ship's vertical motion (heave), which is not completely neutralized by ODP's wireline heave motion compensator (Goldberg, 1990). Data were referenced (according to depth) to the geochemical string run for Holes $829 \mathrm{~A}$ and $830 \mathrm{C}$ and to the quadcombination string run for Holes $831 \mathrm{~B}$ and $833 \mathrm{~B}$.

\section{Calculation of K, Th, and U from NGT Data}

This routine calculates the concentrations of $\mathrm{K}$, Th, and $\mathrm{U}$ from the natural gamma-ray spectrum detected by the NGT (Lock and Hoyer, 1971). The recorded spectrum is divided into five discrete energy windows, with the three windows at the high-energy end covering a char-acteristic peak of the three radioactive series. There are relatively few counts in the high-energy range where peak discrimination is best; thus, a contribution from the high count rate, low-energy part of the spectrum is included to improve the count statistics. The counts from the five energy windows are inverted at each depth level to give the concentrations of $\mathrm{K}, \mathrm{Th}$, and $\mathrm{U}$. This procedure is done at sea, but is improved on shore by the inclusion of caliper and temperature logs in the calculation. The onshore calculation also corrects for $\mathrm{K}$ present in the borehole fluid when $\mathrm{KCl}$ is added to inhibit clay swelling. A 7-point ( $3.5 \mathrm{ft}$ ) filtering window was applied to the raw input data to reduce noise in the logs. The outputs of this program are $\mathrm{K}$ (wet weight percent), Th (ppm), and $\mathrm{U}$ (ppm), as well as a total gamma-ray curve and a computed gamma-ray curve $(\mathrm{Th}+\mathrm{K})$. Although the NGT is run on all of the tool strings, the data shown for each of the logged holes (Figs. $4,6,8$, and 10) are taken from the geochemical tool run, as this is performed at the lowest logging speed and hence provides the best count statistics.

\section{Calculation of Aluminum Concentration}

The fourth processing routine calculates the concentration of $\mathrm{Al}$ in the formation using the data recorded by the AACT. This procedure performs corrections on the raw data for borehole fluid, formation capture cross section, formation slowing-down length, formation density, and borehole size. Count rates of gamma rays from the AACT are combined with those from the NGT to subtract out background radiation; the concentration of $\mathrm{Al}$ is derived from the residual. The measurement is highly dependent on the ${ }^{252} \mathrm{Cf}$ neutron source strength. The source is calibrated by a routine that automatically accounts for source decay.

After the calculation of the wet weight percentage of $\mathrm{Al}$, density and porosity logs are used to convert both $\mathrm{Al}$ and $\mathrm{K}$ from the previous routine to dry weight percentages. The porosity is derived from one of the following: the neutron porosity tool, the induction logs, applying Archie's law (Archie, 1942), or from the density logs, using the following equation:

$$
\phi=(\rho M a-\rho) /(\rho M a-\rho F l),
$$

where: $\phi=$ porosity, $\rho M a=$ matrix density, obtained from core measurements in $\mathrm{g} / \mathrm{cm}^{3}, \rho b=$ bulk density from the log in $\mathrm{g} / \mathrm{cm}^{3}$, and $\rho F l=$ fluid density $\left(\sim 1.05 \mathrm{~g} / \mathrm{cm}^{3}\right)$.

The best porosity log is determined from comparison with shipboard core porosity measurements. For Holes 829A, 831B, and 833B the porosity curve was derived from the lithodensity tool, as shown above, and from the induction log for Hole 830C.

Finally, a correction is made for $\mathrm{Al}$ produced by fast neutron interactions with $\mathrm{Si}$, which occur when $\mathrm{Si}$ becomes activated by the ${ }^{252} \mathrm{Cf}$, causing a reaction that produces the ${ }^{28} \mathrm{Al}$ isotope. The AACT data are combined with the elemental yields from the GST and the K from the NGT to determine the background $\mathrm{Si}$ interference, which is subtracted from the $\mathrm{Al} \log$. The program outputs $\mathrm{Al}$ and $\mathrm{K}$, which are used in the following closure model.

\section{Conversion of Elemental Yields to Elemental Weight Fractions (Hertzog et al., 1989)}

Relative concentrations of the GST-derived elemental yields can be determined by dividing each elemental yield by a relative spectral sensitivity factor, $\mathrm{S}_{i}$. This factor is principally related to the thermal neutron capture cross sections of the various elements. The relative elemental concentrations are related to the desired absolute concentrations by a depth-dependent normalization factor, $F$, as defined by the relationship:

$$
W t_{i}=F Y_{i} / S_{i}
$$

where $W t_{i}=$ absolute elemental concentration, $F=$ normalization factor, $Y_{i}=$ relative elemental yield, and $S_{i}=$ spectral sensitivity factor.

The normalization factor is calculated based on the assumption that the sum of all the elemental weight fractions is $100 \%$. The closure model accounts for $\mathrm{C}$ and $\mathrm{O}$, which are not measured by this tool string, by approximating their amounts in combination with each of the measurable elements as a single oxide or carbonate. The dry 
weight percentages of $\mathrm{Al}$ and $\mathrm{K}$ are normalized with the reconstructed elemental yields to determine $F$ at each depth interval from the following equation:

$$
F\left[\Sigma X_{i} Y_{f} / S_{i}\right]+X_{\mathrm{K}} W t_{\mathrm{K}}+X_{\mathrm{Al}} W t_{\mathrm{Al}}=1.0
$$

where $X_{i}=$ weight of oxide or carbonate/weight of element $i$, and the subscripts $\mathrm{K}$ and $\mathrm{Al}$ refer to the potassium and aluminum components.

Since the closure relationship by nature only involves elements in the rock matrix, no contribution from the borehole or pore fluids needs to be taken into consideration. The model compensates for tool standoff and washouts by automatically increasing the normalization factor.

\section{Calculation of Oxide Percentages}

The final routine converts the elemental weight percentages into oxide percentages by multiplying each element by its associated oxide factor (Table 1). To overcome the problem of variable $\mathrm{Ca}$ oxide factor in the clay and carbonate intervals, $\mathrm{Ca}$ is calculated as $\mathrm{CaO}$ (as opposed to $\mathrm{CaCO}_{3}$ ) for Leg 134 data, and shipboard core-based carbonate measurements have been converted to $\mathrm{CaO}$ for comparison.

\section{COMPARISON OF GEOCHEMICAL LOGS TO CORE}

\section{Site 829}

The processed natural gamma-ray logs from Hole 829A are displayed in Figure 4. The main variations in lithostratigraphic Units I to VI are described in terms of varying chalk and clay components. Clayrich Unit III is defined by sharp increases in K, U, and Th values. All of the gamma-ray logs peak sharply in the middle of Unit IV; this bed was not recovered, but it is probably a thin, clay-rich unit within the chalk breccia. Unit VII, a volcanic breccia, shows higher $\mathrm{K}$ values relative to Th and U. Below Unit VII several thin units with alternating silty clay and chalk components are reflected in the gamma-ray signals.

The oxide weight fractions are shown in Figure 5 with the calculated statistical uncertainties of each element, based on the equations of Grau et al. (1990). This error estimate is closely related to the normalization factor (Eq. 3), which is calculated at each depth interval and is displayed on the right-hand side of the figure. A lower normalization factor indicates better counting statistics - more signal from the formation - and, hence, higher quality data. The large spikes in the normalization factor around $400 \mathrm{mbsf}$ are due to a large borehole diameter in the volcanic breccia and result in a large statistical error for the calculated oxides. Overall, the oxides agree well with the core-based lithostratigraphic classification (Shipboard Scientific Party, 1992a). CaO values from the geochemical logs show an excellent cor- relation with $\mathrm{CaO}$ derived from shipboard core carbonate measurements.

\section{Site $\mathbf{8 3 0}$}

The processed natural gamma-ray curves and oxide weight fractions for Hole 830C are shown in Figures 6 and 7, respectively. The core recovery column represents Holes $830 \mathrm{~A}$ and $830 \mathrm{~B}$, whose water depths were $9.5 \mathrm{~m}$ deeper than that of Hole $830 \mathrm{C}$, which was logged but not cored at the depths shown. This difference makes exact depth correlation of unit boundaries difficult.

Hole $830 \mathrm{C}$ is subdivided into two main lithostratigraphic units, based primarily on the recovered core from other holes at the site. Unit I is predominantly a clay-rich volcanic siltstone and extends from the seafloor to $175 \mathrm{mbsf}$. The logs show small-scale variability but no definite trends within this unit, in which recovery was poor. The boundary with underlying Unit II is characterized by an increase in $\mathrm{Si}$, $\mathrm{Fe}$, and $\mathrm{Ti}$ oxides and a corresponding decrease in $\mathrm{Al}$ and $\mathrm{K}$ oxides. This is a reflection of the change from the clay-rich Unit I into the more silicic and coarse Unit II. This boundary appears at a higher level ( 167
Table 1. Oxide factors for closure normalization.

\begin{tabular}{lll}
\hline Element & \multicolumn{1}{c}{ Oxide } & $\begin{array}{c}\text { Conversion } \\
\text { factor }\end{array}$ \\
\hline $\mathrm{Si}$ & $\mathrm{SiO}_{2}$ & 2.139 \\
$\mathrm{Ca}$ & $\mathrm{CaO}$ & 1.399 \\
$\mathrm{Fe}$ & $\mathrm{FeO}$ (total $\mathrm{Fe}$ ) & 1.358 \\
$\mathrm{~K}$ & $\mathrm{~K}_{2} \mathrm{O}$ & 1.205 \\
$\mathrm{Ti}$ & $\mathrm{TiO}_{2}$ & 1.668 \\
$\mathrm{Al}$ & $\mathrm{Al}_{2} \mathrm{O}_{3}$ & 1.899 \\
\hline
\end{tabular}

$\mathrm{m}$ ) on the logs than is suggested by the recovered core. The more coarse and porous nature of Unit II, coupled with a larger hole diameter, leads to a greater statistical uncertainty in the oxide data, which is clearly illustrated by the uncertainty estimates in Figure 7.

$\mathrm{CaO}$ values from the geochemical logs resemble the mean of those derived from shipboard core measurements. Poor core recovery, leading to depth uncertainty in the core measurements, precludes comparison of the small-scale variability.

\section{Site 831}

In Hole $831 \mathrm{~B}$ the geochemical logs span Units I-III, a thick sequence of almost pure carbonates with very little lithostratigraphic variation. These units overlie a brecciated andesitic basement that was not fully reached by the geochemical tool string because of hole fill. The natural gamma-ray curves from the geochemical string at Hole $831 \mathrm{~B}$ are displayed in Figure 8. Figure 9 shows the oxide weight fractions with calculated uncertainties.

The total gamma-ray curve shows a fair degree of variation in lithostratigraphic Unit II. This variation mainly is caused by uranium (U) variations in the formation. Uranium is associated with organic matter in coral-rich zones. The correlation between high uranium levels and recovered coral is high (Shipboard Scientific Party, 1992c). The logs exhibit virtually no variation in the major element chemistry of dominant $\mathrm{CaO}$. This $\log$ agrees with the few core measurements $\left(\mathrm{CaCO}_{3}\right.$-derived $\left.\mathrm{CaO}\right)$, with the exception of four measurements taken between 670 and $730 \mathrm{mbsf}$, where unrepresentative sampling of small heterogeneities within the core material cause discrepancies. Major elements other than $\mathrm{Ca}$ are probably all at or below the resolution levels of the geochemical tool. Small-scale variation primarily is caused by statistical noise.

\section{Site 833}

The processed natural gamma-ray curves over the interval of 875 to $555 \mathrm{mbsf}$ are displayed in Figure 10. These open-hole logs cover the bottom portion of lithostratigraphic Units III, IV, and the upper part of Unit V. The individual and total gamma-ray curves show fairly low concentrations of $\mathrm{K}$, Th, and U in Units III and IV, which consist of calcareous volcanic silt and sandstone. A few thin, more clay-rich zones are identified by spikes in all of the gamma-ray curves. Unit V, which consists of thick basaltic sills interbedded with thin calcareous volcanic siltstones, is characterized by a sharp increase in total gammaray count, attributable mainly to an increase in $\mathrm{K}$ and Th contents.

The oxide weight fractions are shown in Figure 11 with their respective calculated statistical uncertainties. The low and constant value of the normalization factor is an indication that the data are of good quality. The oxides exhibit only small-scale variability in Units III and IV. Core- and log-derived $\mathrm{CaO}$ values correlate well throughout the hole. The basaltic sills of lithostratigraphic Unit V, defined by the oxide logs, show an increase in $\mathrm{Fe}, \mathrm{Si}, \mathrm{K}$, and $\mathrm{Ti}$ oxides and trace elements $\mathrm{Gd}$ and $\mathrm{Th}$, and a corresponding decrease in $\mathrm{CaO}$, at the upper boundary of Unit V. Results of X-ray fluorescence (XRF) on eleven core samples within the basaltic sills show a good correlation with log-derived oxides. 


\section{SUMMARY}

The reprocessing of natural gamma-ray logs improves the measurements obtained in the field by incorporating the environmental corrections described. Geochemical logs, converted from relative elemental yields to elemental and oxide weight fractions, generally compare very well with the available shipboard carbonate and XRF measurements, thus augmenting the results obtained from studies of recovered core.

\section{ACKNOWLEDGMENTS}

The authors would like to thank Elizabeth Lewis Pratson for her generous attention to the text and figures.

\section{REFERENCES*}

Archie, G.E., 1942. The electrical resistivity $\log$ as an aid in determining some reservoir characteristics. Trans. Am. Inst. Min. Metall. Pet. Eng., 146:54-62.

Bristow, J.F., and deMenocal, P.B., 1992. Evaluation of quality of geochemical log data in Hole 798B. In Tamaki, K., Suyehiro, K., Allan, J., McWilliams, M., et al., Proc. ODP, Sci. Results, 128 (Pt. 2): College Station, TX (Ocean Drilling Program), 1021-1035.

Collot, J.-Y., Greene, H.G., Stokking, L.B., et al., 1992. Proc. ODP, Init. Repts., 134: College Station, TX (Ocean Drilling Program).

Goldberg, D., 1990. Test performance of the Ocean Drilling Program wireline heave motion compensator. Sci. Drill., 1:206-209.

Grau, J.A., and Schweitzer, J.S., 1989. Elemental concentrations from thermal neutron capture gamma-ray spectra in geological formations. Nucl. Geophys., 3:1-9.

Grau, J.A., Schweitzer, J.S., and Hertzog, R.C., 1990. Statistical uncertainties of elemental concentrations extracted from neutron induced gamma-ray measurements. IEEE Trans. Nucl. Sci., 37:2175-2178.
Hertzog, R., Colson, L., Seeman, B., O'Brien, M., Scott, H., McKeon, D., Wraight, J., Grau, J., Ellis, D., Schweitzer, J., and Herron, M., 1989. Geochemical logging with spectrometry tools. SPE Form. Eval., 4:153162.

Jarrard, R.D., and Lyle, M., 1991. High-resolution geochemical variations at Sites 723, 728, and 731: a comparison of $x$-ray fluorescence and geochemical logs. In Prell, W.L., Niitsuma, N., et al., Proc. ODP, Sci. Results, 117: College Station, TX (Ocean Drilling Program), 473-498.

Lock, G.A., and Hoyer, W.A., 1971. Natural gamma-ray spectral logging. Log Analyst, 12:3-9.

Scott, H.D., and Smith, M.P., 1973. The aluminum activation log. Log Analyst, 14:3-12.

Shipboard Scientific Party, 1992a. Site 829. In Collot, J.-Y., Greene, H.G., Stokking, L.B., et al., Proc. ODP, Init. Repts., 134: College Station, TX (Ocean Drilling Program), 179-260.

, 1992b. Site 830. In Collot, J.-Y., Greene, H.G., Stokking, L.B., et al., Proc. ODP, Init. Repts., 134: College Station, TX (Ocean Drilling Program), 261-315.

, 1992c. Site 831. In Collot, J.-Y., Greene, H.G., Stokking, L.B., et al., Proc. ODP, Init. Repts., 134: College Station, TX (Ocean Drilling Program), 317-386.

, 1992d. Site 833. In Collot, J.-Y., Greene, H.G., Stokking, L.B., et al., Proc. ODP, Init. Repts., 134: College Station, TX (Ocean Drilling Program), 479-557.

-Abbreviations for names of organizations and publications in ODP reference lists follow the style given in Chemical Abstracts Service Source Index (published by American Chemical Society).

Date of initial receipt: 19 May 1992

Date of acceptance: 14 December 1992

Ms 134SR-035 


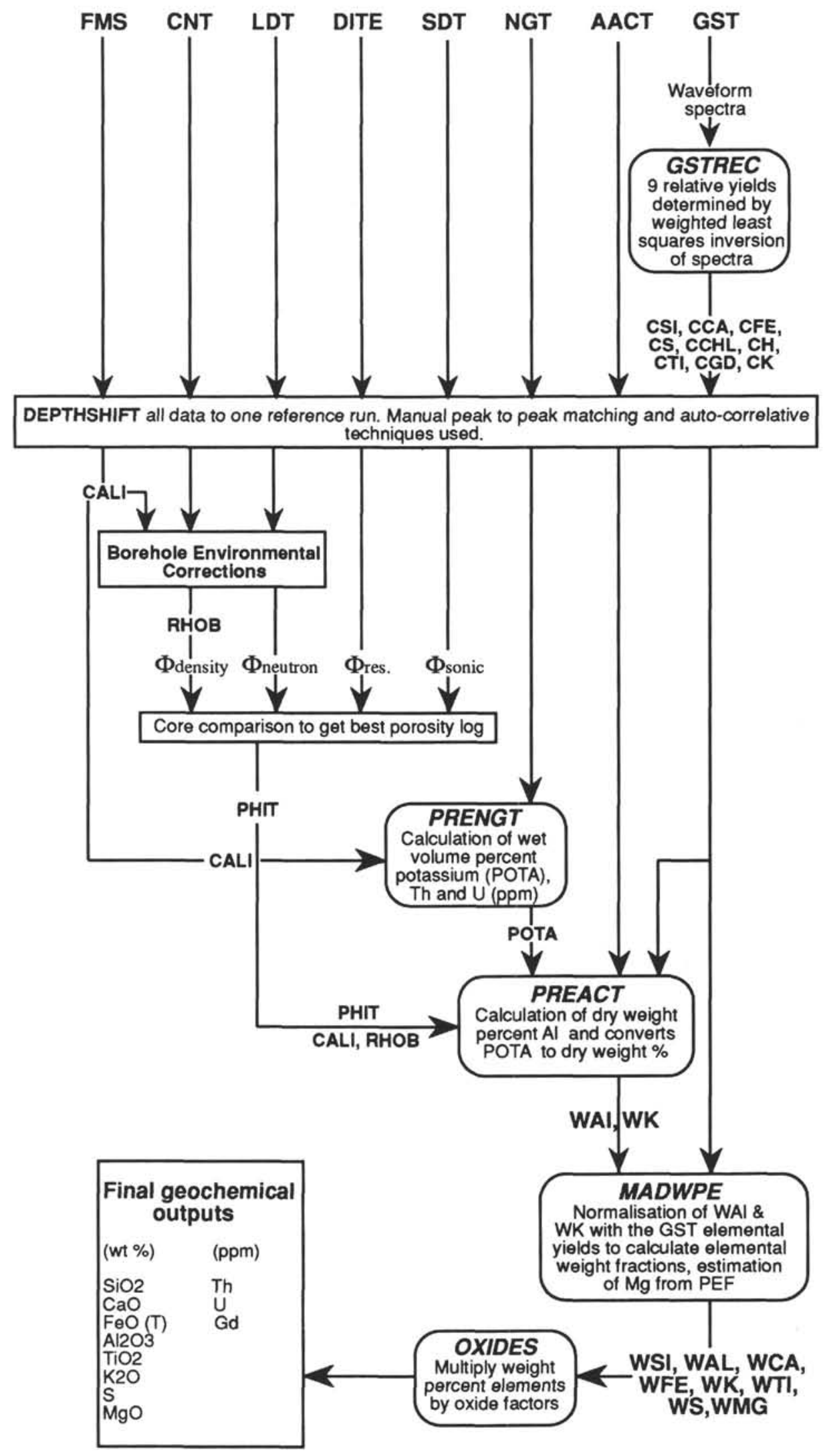

Figure 3. Flow diagram summarizing the post-cruise processing of the geochemical logging data. Schlumberger logging tool acronyms: FMS $=$ formation microscanner tool, $\mathrm{CNT}=$ compensated neutron tool, $\mathrm{LDT}=$ lithodensity tool, DITE $=$ dual induction tool, $\mathrm{SDT}=$ digital sonic tool, $\mathrm{NGT}=$ natural gamma-ray spectrometry tool, $\mathrm{AACT}=$ aluminum activation clay tool, $\mathrm{GST}=$ gamma-ray spectrometry tool. $\mathrm{CALI}=$ caliper, $\mathrm{RHOB}=$ bulk density, PHIT = porosity. Elements with prefix $\mathrm{C}$ refer to the relative elemental yields; elements with the prefix W refer to the dry-weight percentages of the respective elements. Processing routine names are in bold italics. 

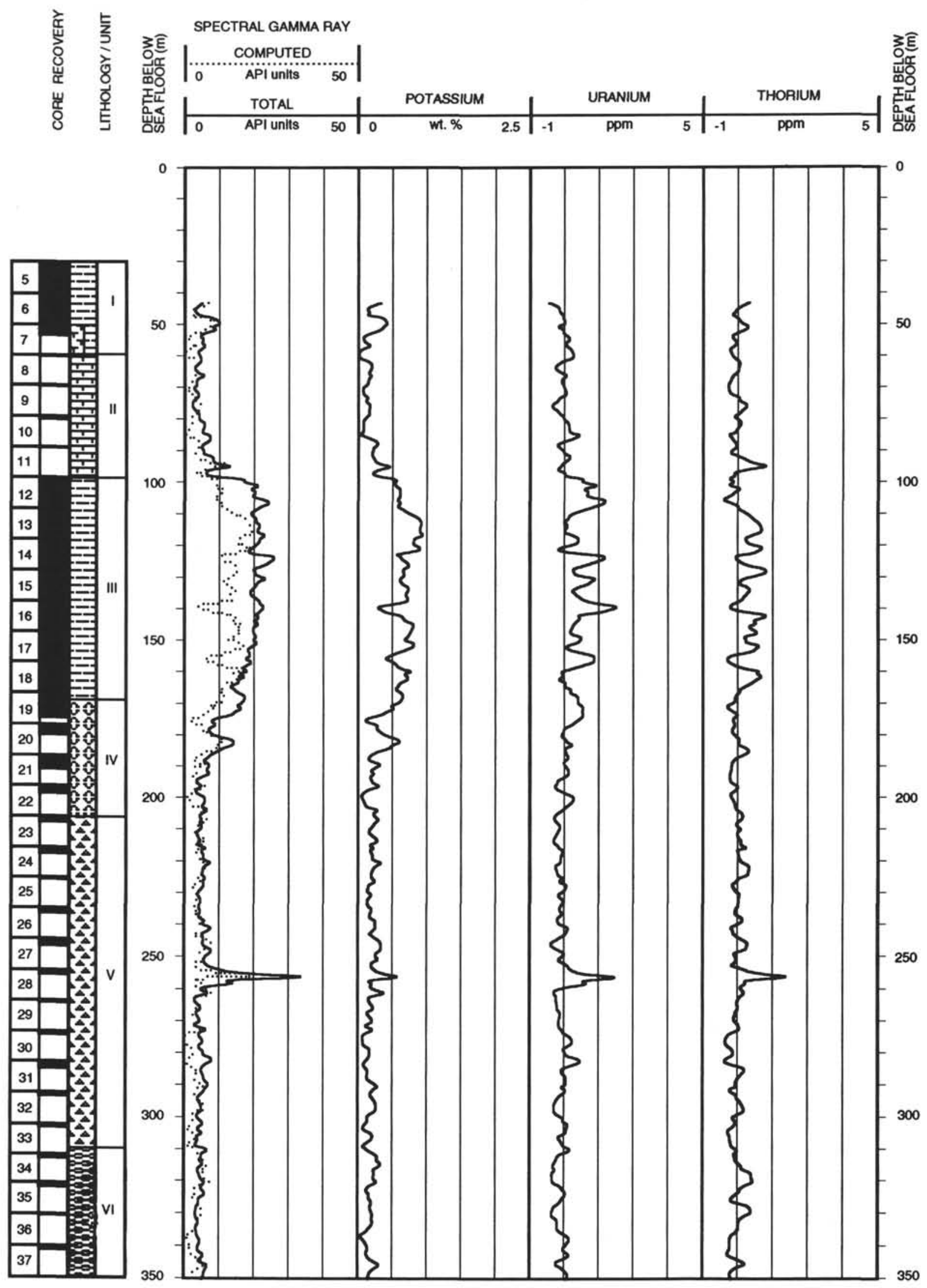

Figure 4. Processed natural gamma-ray data from the NGT for Hole 829A. 

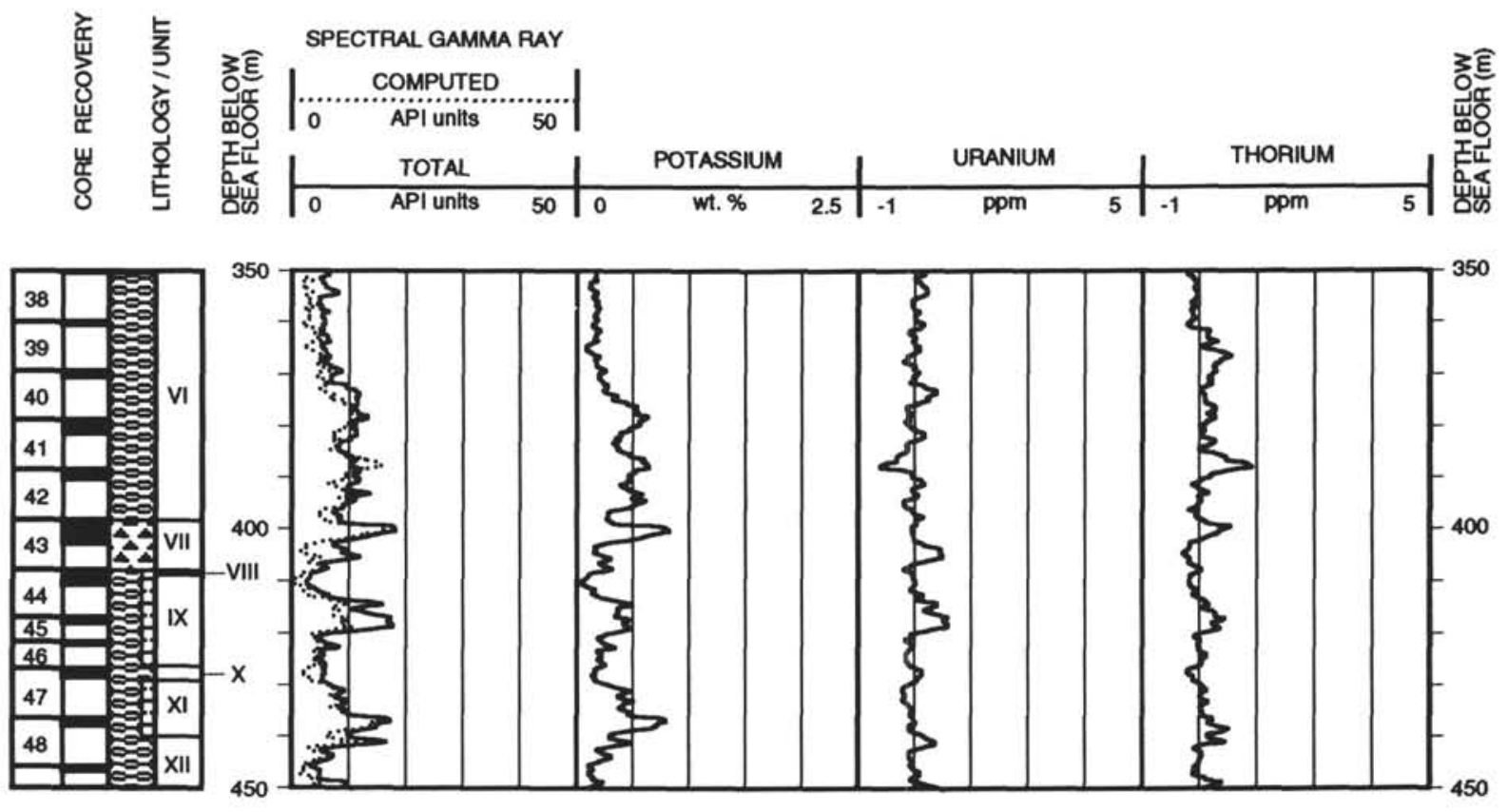

LEG 134: LEGEND OF LTHOLOGIC SYMBOLS

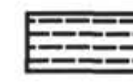

Clayey volcanic silt/sillstone

Foraminiferal chalk

Siltstone-chalk breccla

Sed-lithic breccla with igneous fragments Chalk breccla

Calcareous chalk

Ig-lithic breccla

Volcanic breccia

Silt/siltstone

Calcareous volcanic sitt

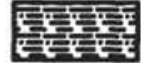

Sllty clay/ctayey sitt
Clayey volcanic silt

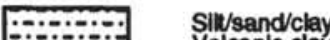

Volcanic clayey sandy slit

Volcanic sandstone

Sandy volcanic siltstone with calcareous grains

Limestone

Andestic breccla with oxidized fragments and some reworking

Nannofossill chalk

Igneous rock

Figure 4 (continued) 

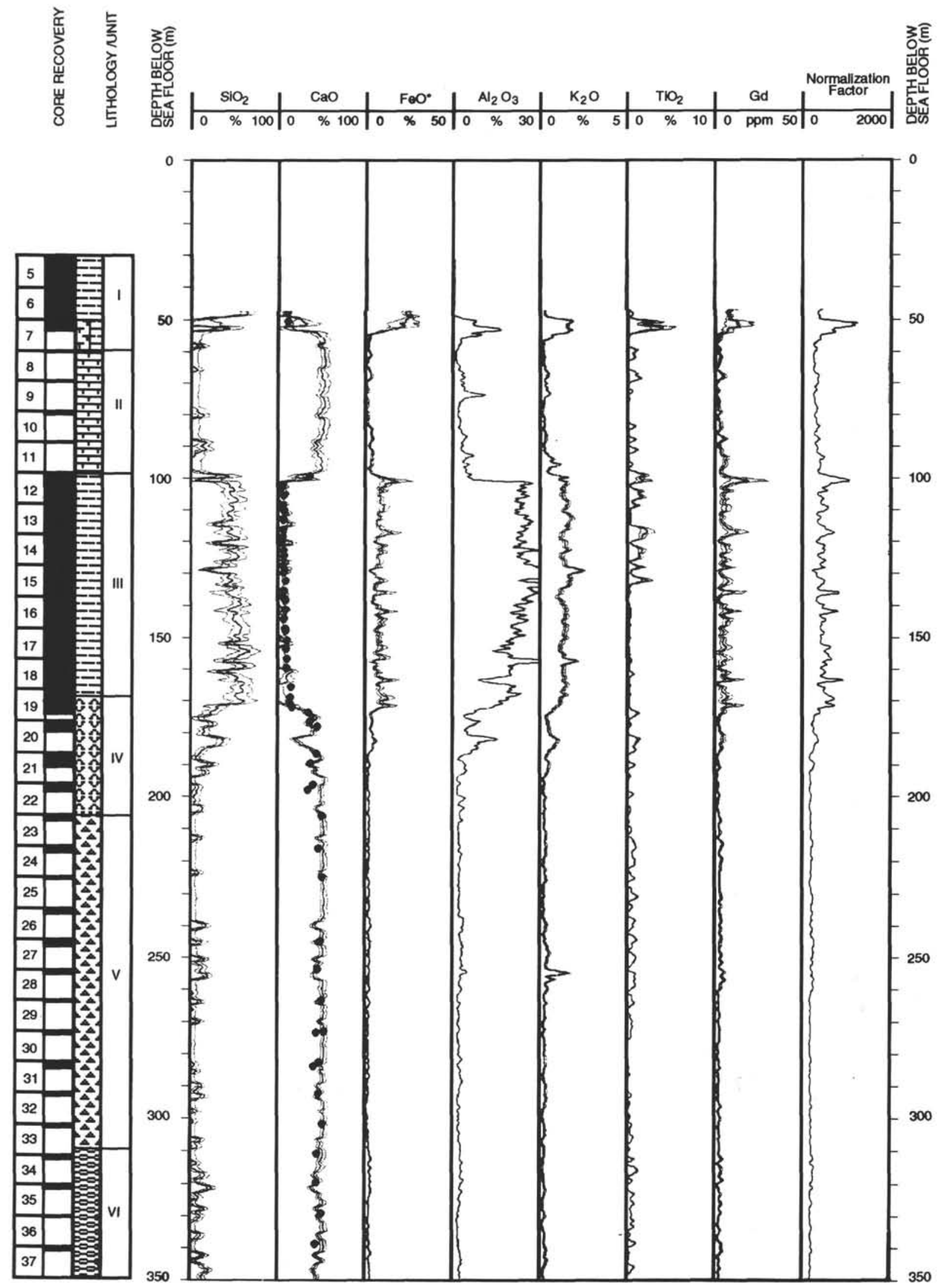

Figure 5. Estimates of major oxide weight fractions derived from the geochemical logging tool for Hole 829A. Solid circles represent $\mathrm{CaO}$ values derived from shipboard carbonate measurements of core. Solid diamonds represent core XRF measurements of major oxides. See Figure 4 for key to lithology. 

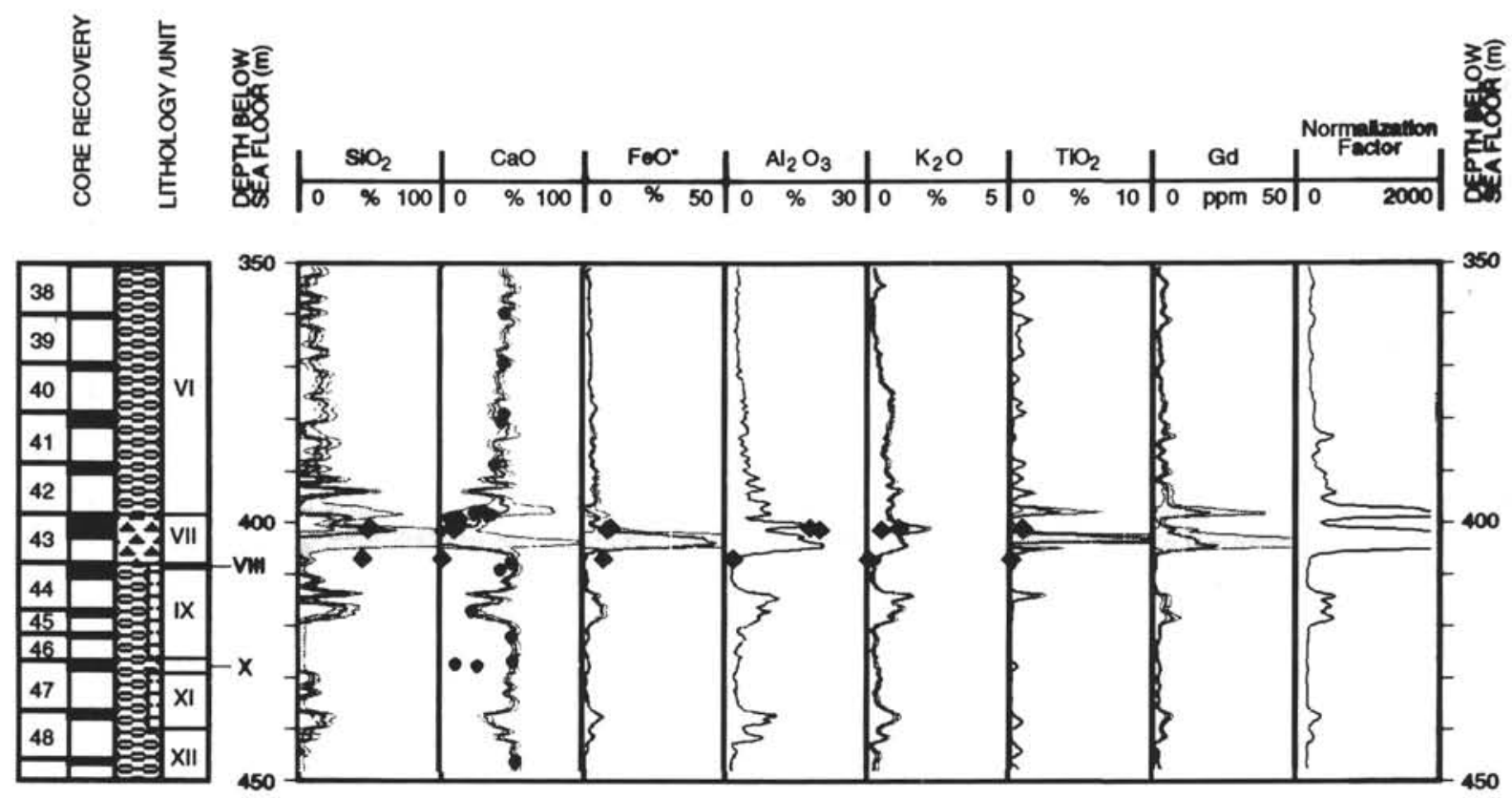

Figure 5 (continued). 

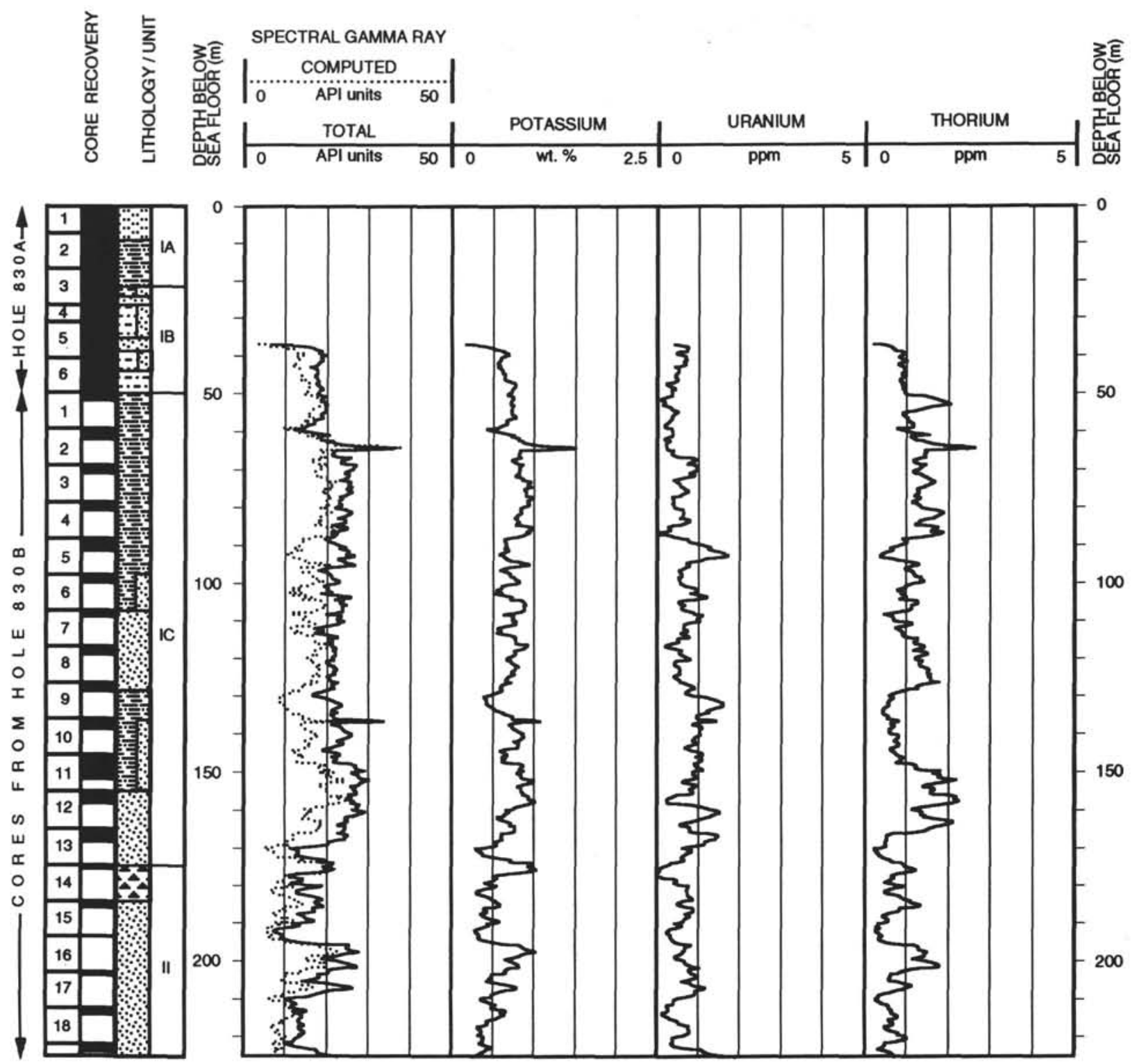

Figure 6. Processed natural gamma-ray data from the NGT for Hole 830C. See Figure 4 for key to lithology. 

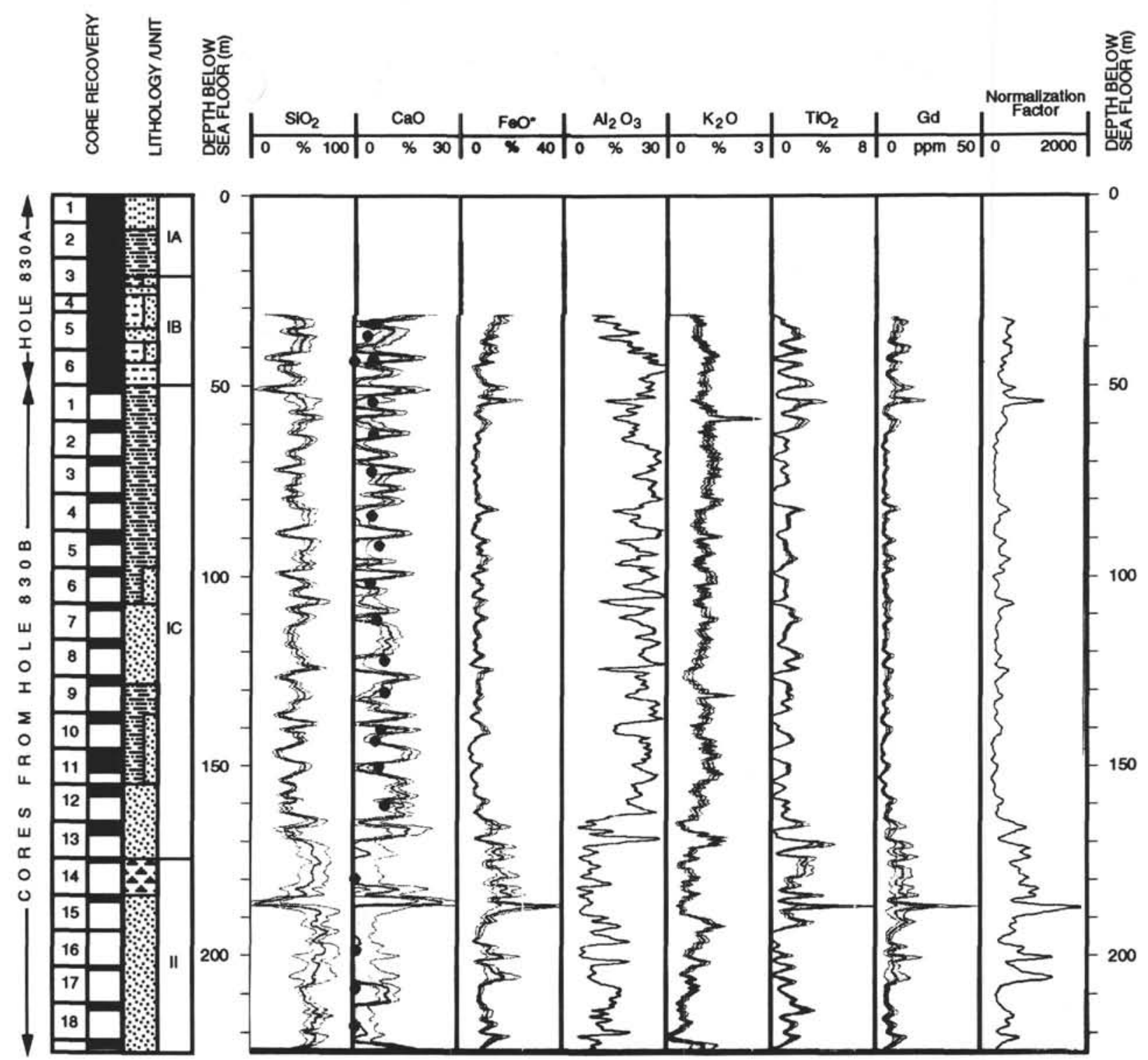

Figure 7. Estimates of major oxide weight fractions derived from the geochemical logging tool for Hole $830 \mathrm{C}$. Solid circles represent $\mathrm{CaO}$ values derived from shipboard carbonate measurements of core. See Figure 4 for key to lithology. 

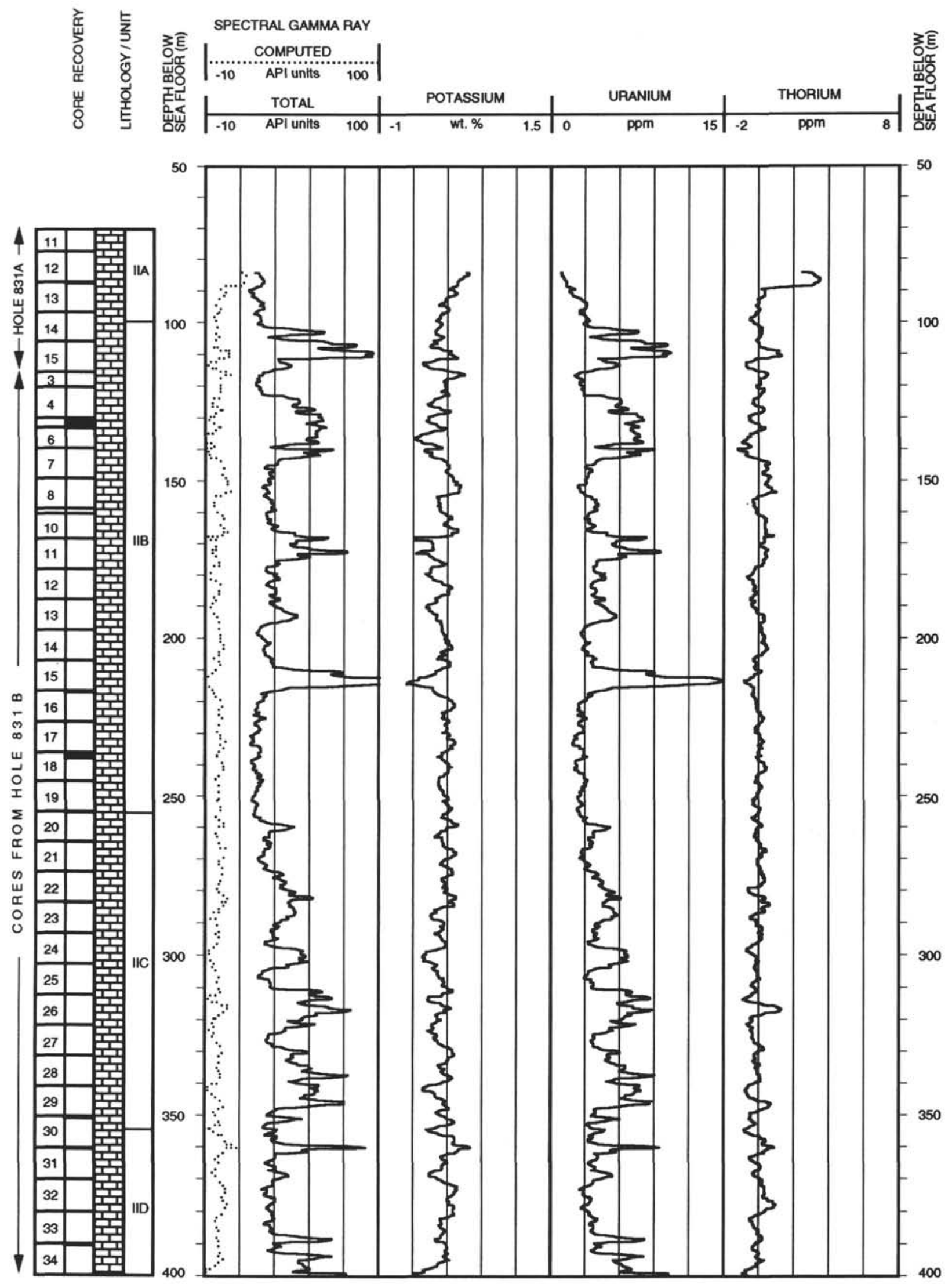

Figure 8. Processed natural gamma-ray data from the NGT for Hole 831B. See Figure 4 for key to lithology. 

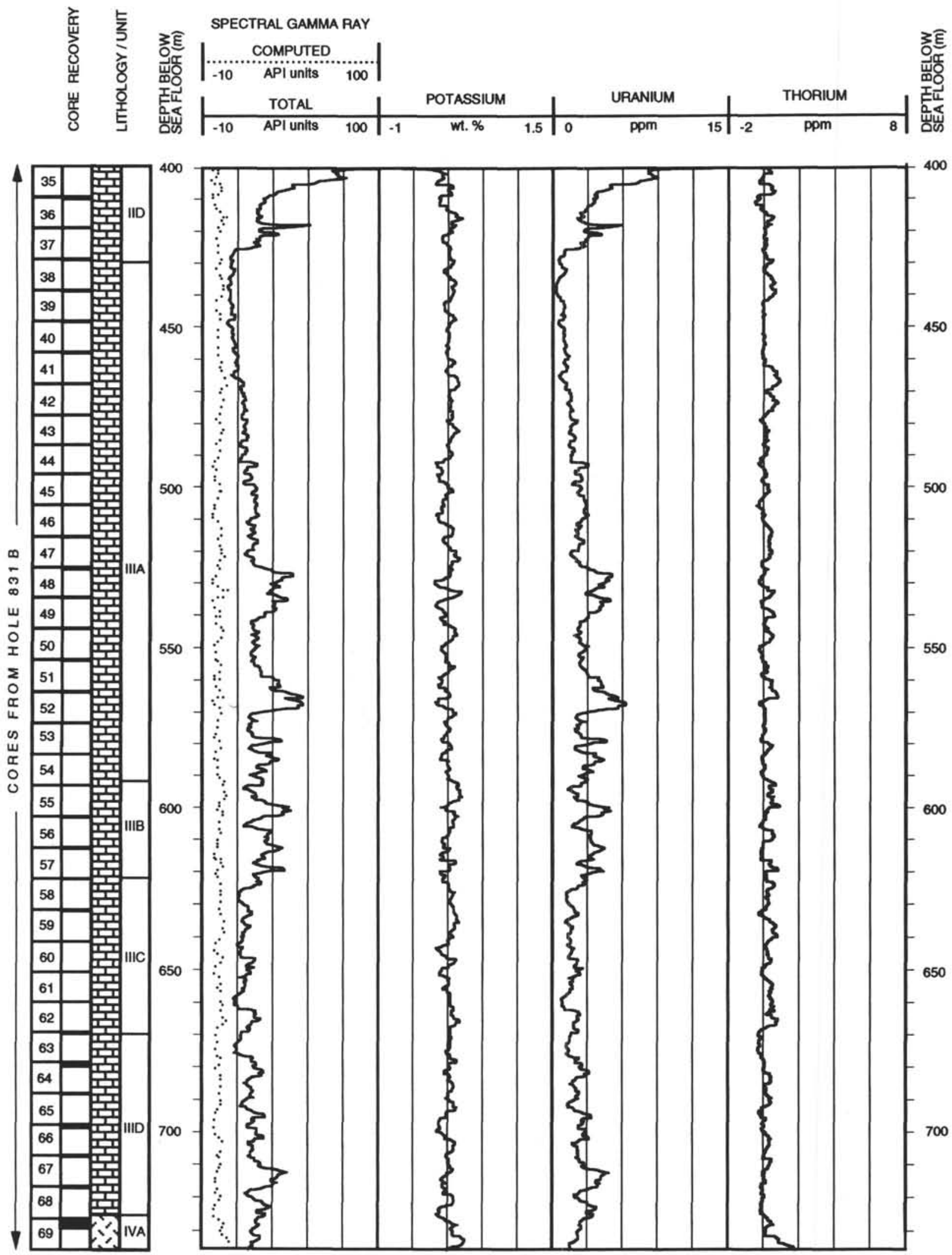

Figure 8 (continued). 

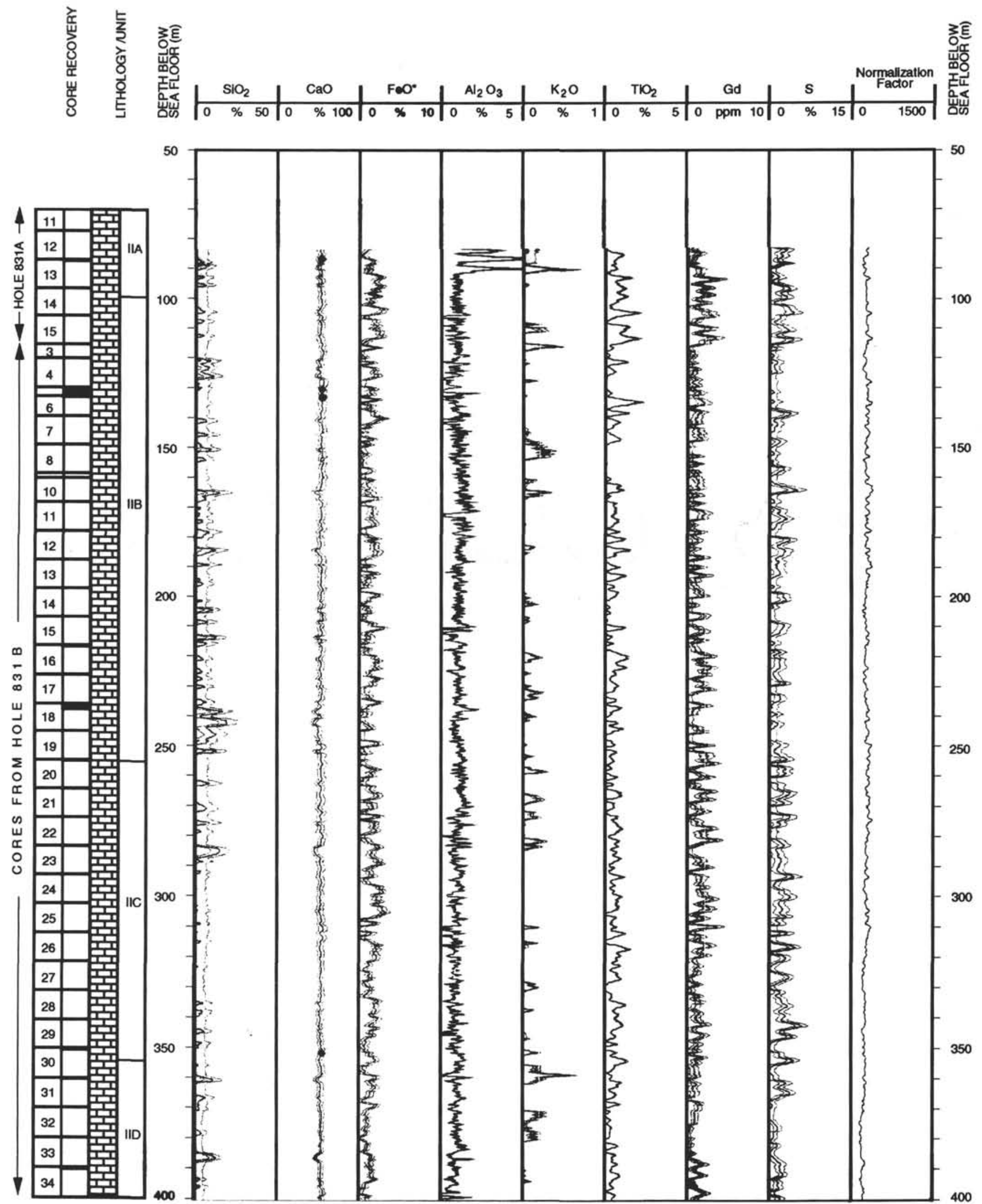

Figure 9. Estimates of major oxide weight fractions derived from the geochemical logging tool for Hole 831B. Solid circles represent CaO values derived from shipboard carbonate measurements of core. See Figure 4 for key to lithology. 

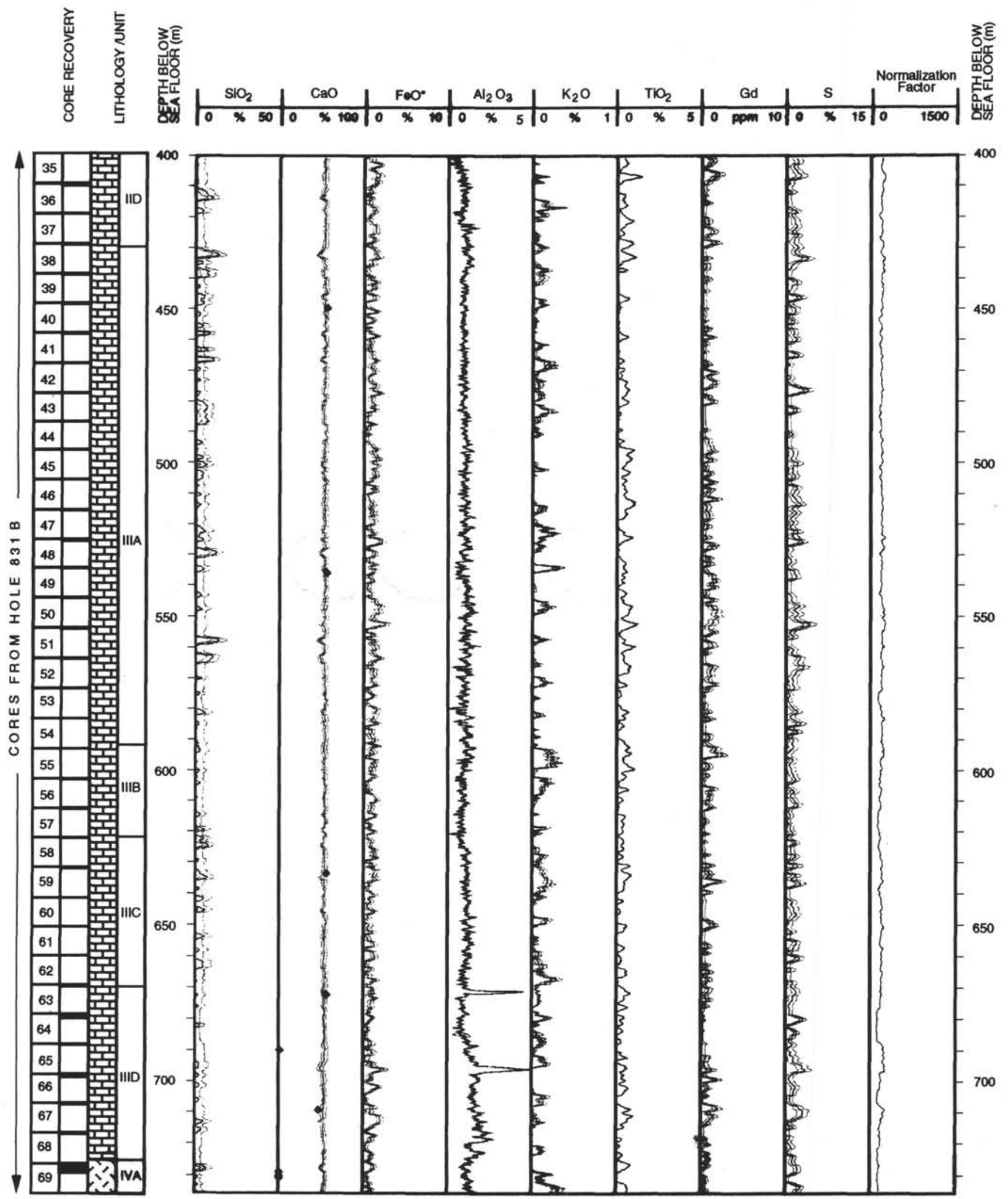

Figure 9 (continued). 

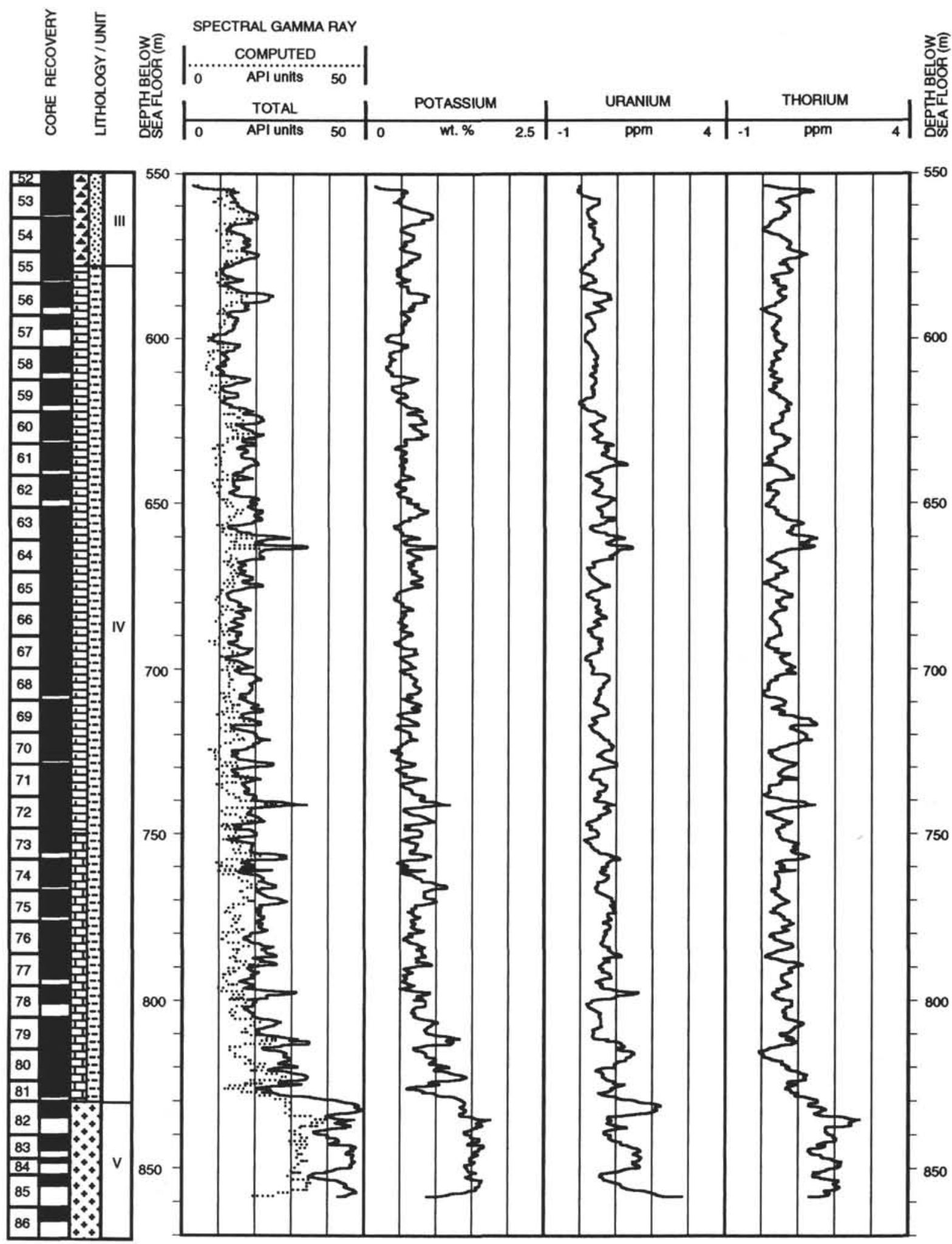

Figure 10. Processed natural gamma-ray data from the NGT for Hole 833B. See Figure 4 for key to lithology. 

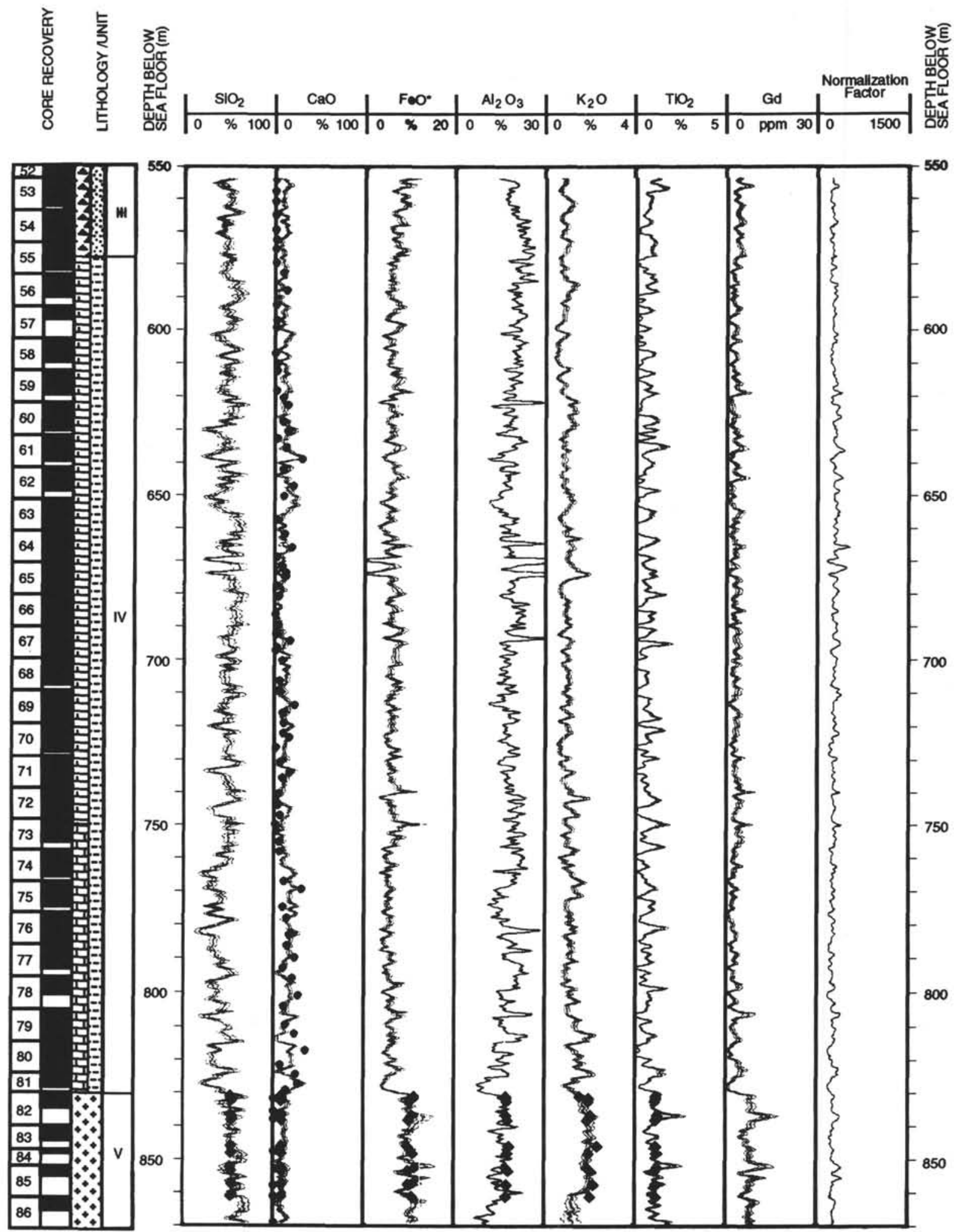

Figure 11. Estimates of major oxide weight fractions derived from the geochemical logging tool for Hole $830 \mathrm{C}$. Solid circles represent $\mathrm{CaO}$ values derived from shipboard carbonate measurements of core. See Figure 4 for key to lithology. 